\title{
MARINE AND FRESHWATER BEACHES OF ONTARIO
}

\author{
BY A. P. COLEMAN
}

(Read before the Society December 28, 1900)

\section{CONTENTS}

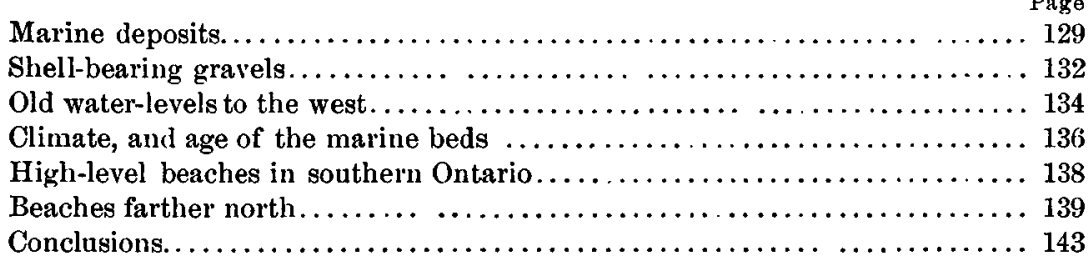

\section{Marine Deposits}

The Pleistocene marine beds of Ontario have been studied for many years and have yielded a great number of fossils at different points along the Saint Lawrence and Ottawa and in the country between these two rivers, as well as along the rivers flowing north into Hudson bay,* proving that the sea once occupied these regions for a length of time sufficient to form beds of clay and sand often more than 100 feet thick. Sir William Dawson has divided these deposits into "Leda clay" and "Saxicava sand," the names being derived from the commonest fossils occurring in them. The Leda clay usually rests on boulder-clay, and the Saxicava sand usually overlies the Leda clay, so that in general one may say that the stratified marine beds were formed later than the last retreat of the ice from the region mentioned.

Probably the beds most productive in fossils of any of these deposits in Ontario are those in and about Ottawa, and these may be described as typical. The Leda clay is well disclosed in the city itself, and at Greens

* Geol. Can., 1863, pp. 915-928; Can. Ice Age, Sir Wm. Dawson, pp. 203, etcetera; Reports of Dr Bell in the Geol. Survey Can., 1871-'72, p. 112 ; also 1875-'76, p. 340. Dr Ami also has collected many species, some of which are enumerated in the Ottawa Naturalist, vol. xi. no. 1, pp. 20-26. 


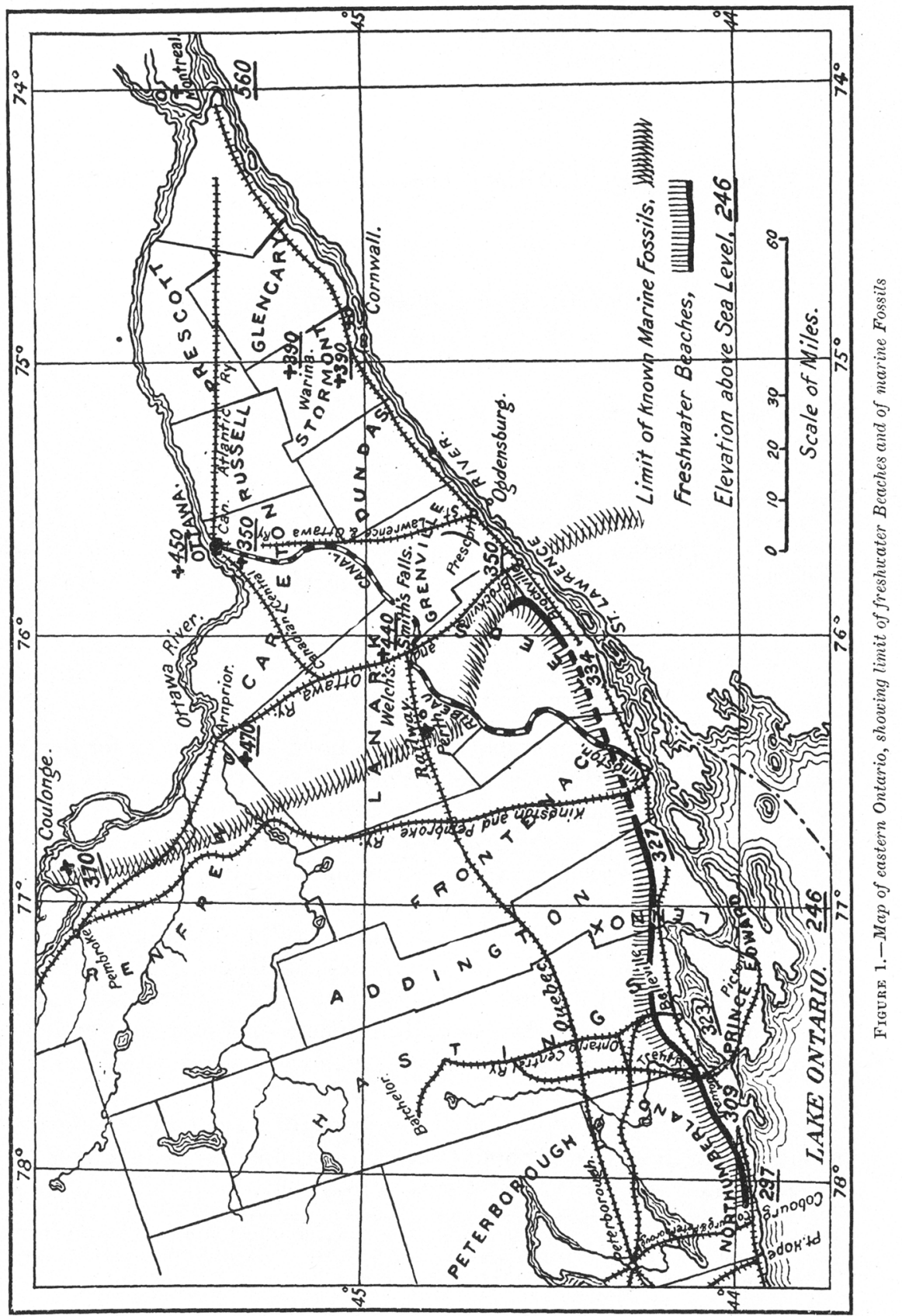


creek and Besserers wharf a few miles down the river. 'The clay, which is bluish gray and well stratified. rises about 40 feet above the Ottawa, or about 160 feet above the sea, and contains in many places great numbers of concretions, well known for the beautifully preserved fossil fish they often enclose. In addition to the capelin (Mrillotus villosus) and two or three other fish, Leda arctica, Saxieava rugosa, and Macoma fragilis, with some other species of shell fish, have been found in the concretions. From brickyards in the city a number of other fossils-shellfish, a sponge, foraminifers, etcetera-have been obtained.

In addition to the marine forms mentioned, a large number of land and freshwater plants and several birds and mammals, including a seal and a chipmunk, have been obtained from the concretions, showing that the Leda clay was formed not far from a shore where clay, with drift materials, was brought down by rivers. Although Leda itself may occur in moderately deep water, most of the other fossils suggest shallow water.

In Nepean township, 6 miles up the Rideau river from Ottawa, the Leda clay rises to about 310 feet above sealevel, but here no concretions are found, and the number of species of shellfish is small. Leda clay with concretions is found 60 miles northwest of Ottawa city, on lake Coulonge, an expansion of Ottawa river, at a height of 370 feet above the sea, according to Doctor Ells,* and at many points down the river and along the Saint Lawrence. Very similar stratified clays occur at levels above this, even up to 1,000 feet, but marine fossils have not been reported in them above 370 feet. The fossiliferous clays near Ottawa are stated to be 140 or more feet in thickness, and as they are very widely spread, their deposit must have demanded a long time. The Leda clay of Montreal and points farther east and northeast along the Saint Lawrence, which will not be referred to here, has been well described by Sir William Dawson in " Canadian Ice Age."

The Saxicava sands cover a greater area than the clays, but contain fewer species of fossils, the usual ones being Saxicava rugosa and Macoma fragilis, whose white, but well preserved, shells could sometimes be collected by bushels. A good exposure of these sands occurs at the point 6 six miles from Ottawa, on the Rideau river mentioned before, where overlying the clay there are about 40 feet of sand, showing more or less cross-bedding and evidently deposited in shallow water.

Beside the two ubiquitous shellfish mentioned above, many shells of Mytilus edultis occur, often beautifully preserved with the two valves still united; and one finds also a few balani. The shells are inost numerous just where the sand and clay join, but are found more or less frequently

* Sands and Clays of the Ottawa Basin, Bull, Geol, Soc, Am., vol. 9, pp. 215 and 216. 
all the way up. The sand rests conformably on the clay, and rises to a level of about 350 feet above the sea. The surface of the adjoining country is sandy, with a somewhat rolling and duny character, but without any well marked shoreline; so that the sand was probably laid down as shoals in shallow water.

Similar sands with shells are reported by Doctor Ells at higher. points farther up the Ottawa-that is, at 470 feet along the summit of rocky ridges to the west of Arnprior.

The sands occur widely spread also in the flat country south of Ottawa, good instances being seen along the Nation river and its tributaries near the villages of Avonmore and Monklands, where drainage operations give good opportunities to study them. Here one finds broad, swampy tracts more or less covered with peat, beneath which is a layer of sand from 2 to 5 feet thick, crowded with shells of saxicava and macoma and resting directly on bluish boulder-clay with no stratified clay intervening. In some places a layer of sand, containing many small freshwater shells of at least eleven species, rests on the marine sand with no apparent break between the two, so that the same spadefull contains both, though there must have been a considerable lapse of time between the formation of the two layers of sand. At some points on the drainage ditch the boulder-clay is missing, and the marine sand, with shells, rests directly on the flat limestone of the region, the boulder-clay having been removed perhaps by erosion. These sand beds are from 320 to 330 feet above sealevel.

The association of freshwater with marine shells in different beds of the same section is, of course, not a new thing, since Sir William Dawson long ago mentioned similar relationships in stratified clay and sand at Pakenham, northwest of Ottawa.*

\section{Sheld-Bearing Gravels}

Still more frequent than shell:bearing sands are banks and ridges of gravel containing the same fossils-Saxicava gravels, as they may be called-which often have a substratum of boulder-clay, and in many cases consist of morainic or kame-like deposits, probably of glacial origin, rearranged by wave action. Many of these. ridges are found in the neighborhood of the villages of Finch and Avonmore, and they are often elongated in a direction of about north 15 degrees or 20 degrees east, which corresponds to the general direction of the glacial striæ of the region. They are not eskers, however, being too short and consisting often of a ridge

* Can. Ice Age, p. 58. 
ofboulder clay, with a few feet of coarse, shelly gravel resting on or against it. It appears as if these ridges formed shoals in the shallow sea, where wave action worked up the stones of the boulder-clay into local gravel deposits, one thin sheet of shelly gravel even lying on top of a drumlin of rather irregular shape west of Finch.

A typical example is found at McMillans gravel pit near the same village, where 12 teet of gravel, with Saxicava rugosa, Macoma fragilis, and Mytilus edulis, rest on 10 feet of very stony boulder-clay, the whole sloping off gently on all sides to the level plain.

One of the largest of these gravel deposits occurs north of Monklands, at a railway ballast pit called Warina, where a steam shovel is at work, exposing a fresh section 30 feet high, showing coarsely stratified gravel and sand, in the lower part containing many boulders, sometimes 3 or 4 feet in diameter. The lower portion of the deposit, which rests on stony clay, shows no shells, but the upper and better stratified gravel and sand look like a beach formation, having thin layers of garnet sand and many shells of saxicava and macoma. This gravel hill runs about north 35 degrees east and rises 390 feet above sealevel.

Many other ridges of the sort, some as large as the one just noted, but most of them smaller and lower, are to be seen in the region; but only the most southerly, near Newington, need be mentioned. The general arrangement here is the same as at Warina, but the hill, which rises to 390 feet also, trends east and west and slopes off gently toward the south, changing in that direction into evenly stratified sand with shells-saxicava sand.

The most westerly of these gravel hills, at Welchs, north of Smiths falls, is famous for the bones of a whale found there in 1882, in a railway ballast pit, at a height of 440 feet above sea. At present little is to be seen at the pit, which has been disused for a number of years. The gravel, which is often bouldery, shows a face of 52 feet, but no shells are to be found in it, and the whole deposit, which is an irregular kamelike ridge, having a shallow kettle hole on top and running north 15 degrees east, like the striæ on the Potsdam sandstone beneath, suggests ice action rather than wave action. Mr Taylor is probably correct in supposing that the bones, which are of Megaptera longimana, a whale now common in the gulf of Saint Lawrence, were deposited in a beach cut on one side of the ridge and not in the ridge itself.

The shell-bearing gravels along the river Saint Lawrence appear to end a little west of Prescott, at the Gladstone gravel pit, opened on a kame consisting often of very coarse materials. There are no shells in the body of the deposit, only in some small patches of silt and gravel 
resting unconformably on the surface of the kame, about 320 feet above the sea, and the only shell observed is Macoma fragilis of unusually large size. A few fragments of the same shell were seen in a gravel ridge rising about 350 feet (aneroid) above sealevel on the south side of the Grand Trunk railway, a mile and a half west of the last point. The bed of gravel is 10 feet thick, rests on a floor of blue clay, probably till, and consists of rather fine, well rounded materials distinctly stratified and sometimes cross-bedded, having all the look of a beach ridge. Not far off to the north of the railway there are rock cliffs which appear to have been cut by wave action.

While no marine shells are to be found west of this at present, Doctor Robert Bell obtained some many years ago at Brockville, 7 miles farther in that direction, in clays penetrated by a tunnel under the town. This is the most inland point at which marine fossils of any kind have been reported.

Doctor Gilbert states that clays and sands rich in shells like those described above are common in the state of New York, south of the Saint Lawrence, but on that side also they appear to cease before reaching Morristown, opposite Brockville.

Gravels, sands, and clays not unlike the marine deposits which have been described occur at various places west of Brockville-for example, at Iyn, Gananoque, and along the bay of Quinte-and some of them have been searched carefully for fossils, but without success, suggesting that for some cause the marine fauna could not advance into the Ontario basin.

\section{Old Watere-Jevels to the West}

While the marine fossils disappear there are evidences of an old waterlevel corresponding to the beach ridge found between Maitland and Gladstone, extending on to the west. At Lyn, a few miles beyond Brockville, rocky hills rise a little way from the river, but at their foot are level clay flats at an elevation of 325 feet above the sea, corresponding fairly well with the beach gravels at 350 , since a beach ridge always stands higher than the clays and silts laid down in enclosed waters.

Similar clay flats are found at Mallorytown, 8 miles farther west, and at Lansdowne. From this point to Ernestown, 35 miles farther, traces of this water-level have not certainly been found, but beyond this it may be seen from point to point, and at Belleville a boulder pavement at 323 feet above the sea probably represents it. Near Brighton the lowest water-level, which is well marked and has a shore cliff of boulder-clay rising 60 or 70 feet above it to the north, stands at 309 feet; and what 
seems to be a continuation of the same shore has been traced as far as Cobourg, where it is at 297 feet above the sea. Beyond this it has not been followed, though a vague water-level near Toronto, rising 20 or 30 feet above lake Ontario, which is 246 feet above sealevel, may be a continuation of it.

Beach lines equivalent to the one mentioned have not yet been reported from New York state, though they should be found there if there were wave action sufficient to form them on the Canadian side. Doctor Gilbert describes a well marked terrace on a hill to the east of the region mentioned, but apparently too far above 350 feet to he a probable continuation of the water-plane traced west of Brockville.

If we suppose the somewhat faintly marked old shore described above to be the continuation of the marine beaches to the east of Brockville, the northeastern part of the region must have been considerably deformed since the Saxicava sands and gravels were laid down, for the finding of bones of a whale at 440 feet at Smiths falls, of shelly sands near Ottawa and Arnprior at 470 feet, and of beaches with shells at 560 feet at Montreal indicates a somewhat rapid rise. Between Maitland and Montreal the average rate of differential elevation is 1.75 feet per mile; and if we take the beach at 615 feet, in which, however, no shells have been found, $*$ it will amount to about two feet per mile. If we compare Welchs, near Smiths falls, at 440 feet, with Ernestown, 60 miles to the southwest, at 327 , the rate is a little under two feet per mile. These are not improbable rates of differential elevation when compared with those worked out for the Iroquois beach to the west, but the variation in level between Maitland and Welchs, 30 miles to the northwest in a line nearly at right angles to the supposed direction of greatest deformation, is 90 feet, or 3 feet to the mile, which seems hard to account for.

It is possible that in the beginning the sea stood for a short time higher than the main beach levels indicate, forming then the deposits at Welchs and the water-line noticed by Doctor Gilbert in New York. The vague character of the beach at Welchs suggests only a short time for wave action. In connection with this it may be mentioned that fairly distinct beaches have been found by myself at various higher levels in the Bay of Quinte region of lake Ontario, on the bay shore of Prince Edward county at 378 feet, northwest of Belleville at 416 feet, and near Trenton at 390 feet; but thus far these fragmentary beaches have not been traced for any distance, and could be correlated only doubtfully with beach levels farther east. If these beaches were of marine formation, the sea probably occupied the region for too short a 
time to leave much impress, and as no fossils occur in them the solution of the problem must remain doubtful.

That the old sealevel at 350 feet continued into the Ontario basin, and may even have reached its western end, seems very probable, and the fact that marine fossils are very abundant east of Brockville, but have never been found to the west, may be accounted for by the narrowing of the lower end of the basin forming a strait not very much wider than the present river and only 100 feet deeper; so that Niagara and the other rivers flowing into lake Ontario were able to keep the waters fresh, or at least only brackish, in spite of their communication with the enlarged gulf of Saint Lawrence.

It may fairly be asked if the beach-like deposits of sand and gravel and also the stratified clays resernbling the Leda clay occurring at higher levels in the region west of the fossiliferous beds may not also be of a marine origin, and geologists who have begun their studies in the maritime provinces, where many elevated sea beaches exist, are inclined to this view. Sir William Dawson, Doctor Ells, and Mr Chalmers have looked on these higher stratified deposits, even up to 1,000 feet to the east of Toronto, as probably marine; $*$ and Doctor Spencer has described the Iroquois beach, rising at Brighton and Trenton 275 or 300 feet above the beach levels referred to in this paper, as formed in an arm of the sea. This conclusion is a very natural one and tends toward simplicity by avoiding the assumption of an ice-dam; but the finding of freshwater shells in the Iroquois beach near Toronto seems conclusive as to the character of the water, which could hardly remain fresh or even brackish with an opening 70 or 80 miles wide and 400 feet deep into the inland sea formed by the enlarged gulf of Saint Lawrence.

If the Iroquois beach is of freshwater origin, there is no need to prove that the higher beach-like deposits are not marine. It may be that some of them were not even formed in standing water, but are glacial and of a kame-like nature, though this can not be stated positively without some field work in the region. As seen from the Canadian Pacific railway, the latter view seems probable in at least a few cases.

\section{Chimate, and Age of 'the makine Beds}

The fossiliferous beds of the Ottawa and Saint Lawrence valleys are sometimes spoken of as interglacial, though they can not be considered interglacial in the same sense as the Toronto formation or other fossiliferous deposits lying between two sheets of till. They usually rest on

* Bull, Geol. Soc. Am., vol. 9, p. 214 ; Geol. Survey Can., vol. x, 1897, pp. 68 and 69 A. 
boulder-clay or a striated rock surface, or form the upper beds of kamelike hills, but have not yet been shown to be covered by boulder-clay or any other well marked glacial materials. It is true that scattered boulders, which may be called erraties, sometimes rest on them, but these have probably been transported by floating ice when the sea stood at its higher level, just as river ice transports large boulders in the Saint Lawrence at the present day.

As to the temperature of the time, the plants found in the Leda clay nodules at Ottawa, 28 species in all, as determined by Professor Penhallow, are all represented in the same region at present, and include the sugar maple, the yellow birch, and the common and balsam poplar, trees of a cool temperate but by no means arctic climate. Of the other fossils much the same may be said. The chipmunk is common in the same region now, the feathers and bone of a bird have not been determined, and the four species of insects-Fornax ledensis, Tenebrio calculensis, Byrrhus otlawnensis, and Phryganea ejecta-as determined by Doctor Scudder, are extinct and do not add much to our data. The seals, dolphins, and whales found in our deposits are all still living in the gulf of Saint Lawrence, and the same is true of most of the 26 other marine animals recorded.* The Arctic species mentioned by Sir William Dawson are apparently still living in the Gulf and do not indicate a climate greatly different from the present, though perhaps somewhat colder, so that these beds are not interglacial even in the sense of having been formed while glacial ice occupied the shores of the inland sea, though it is possible that the Labradorian ice-sheet had not wholly vanished at the time they were being formed.

If the usually accepted theory that the Iroquois water was dammed by glacial means is correct, the marine beds of the Ottawa-Saint Lawrence region could not have been formed until the ice-tongue, hundreds or thousands of feet thick, which obstructed the lower end of the Ontario basin, had melted away, and this provides some data for estimating their age. If we suppose the formation of the Iroquois beach to have taken half the time since Niagara began its work, and this is not an unreasonable supposition, there is available for all subsequent events a time variously estimated at from 2,500 to 16,000 years. Within this time the great ice-dam must have melted, implying a retreat of the glacial front for at least 100 miles, and widespread sheets of sand and laminated clay, sometimes more than 140 feet thick, were laid down, and afterwards eroded to the depth of at least 110 feet by the Rideau and other rivers.

* Can. Ice Age; also contributions to the paleontology of the post-Pliocene of the Ottawa valley, Dr Ami, Ottawa Naturalist, vol. xi, no. 1, pp. 20-26. 
Since the marine beds were formed sufficient time has elapsed to allow the region of Ottawa to rise 470 feet, and that of Montreal 560 or perhaps 615 feet, and within the same time limits apparently 6 species of animals have become extinct-4 insects, an ostracode (Estheria drwsoni), and a sponge (Craniella logani, Daws.).

In addition to the considerations just mentioned, the present beach of lake Ontario, with its fairly mature forms, including the cutting of cliffs hundreds of feet high and the building of gravel bars miles in length, as at Scarboro and Toronto, must have been worked out since the barrier at the Thousand islands came into existence, and therefore since the completion of the marine deposits just to the east, for they rise a hundred feet above it.

Though we do not know the exact rate of any of these operations, all of them seem to demand a large amount of time, and the lower limit, of 2,500 years, let us say since the time of Pericles or the founding of Rome, seems quite inadequate, and even the upper one, of 16,000 years, not too great.

\section{High-Jevel Beaches in southern Ontario}

Two or three hundred feet above the most westerly deposits containing marine fossils is the splendidly developed Iroquois beach, followed by the Nipissing, Algonquin, and Warren shorelines, all very distinct and fairly well known through the labors of Spencer, Gilbert, Taylor, and others. These need not be discussed here, except to mention that a few freshwater shells have been found in the Iroquois beach, and that great numbers of freshwater fossils are found in an extensive area near Georgian bay, probably belonging to lake Algonquin, though possibly to lake Warren, showing that at least two of these higher beaches are not marine.

There are, however, beach deposits at higher levels than any of the old shorelines mentioned, the highest of which, so far as recorded, reaches 1,230 feet above the sea.* On the highlands of the peninsula between lake Huron and Georgian bay Doctor Spencer has found several fragments of beaches, around what must have been an old island, at levels from 1,400 to 1,690 feet, $\dagger$ and similar beaches have been described by the present writer at points 1,422 to 1521 feet above the sea in the same district.f Some of these are well marked water-levels, with broad terraces

* Mr Taylor mentions water-levels at 1,200 to 1,230 feet near Trout creek, Cartier, etcetera, probably belonging to the Algonquin shores. Am. Geol,, vol. xiv, 1894, p. 285 . He describes also beaches at 1,530 or 1,540 feet west of Port Arthur, belonging, however, to a relatively small icedammed lake which he has named lake Kaministiquia.

† History of the Great Lakes, p. 78.

$\ddagger$ Bur. Mines Ont., 1!00, pp. 176, 177. 
and rock cliffs in the rear, and can hardly be accounted for as belonging to the extraordinary river valley described by Mr Taylor farther south on the same escarpment, where only one-half of the channel of the river is left, its eastern side, which was of ice, having melted away. As examples may be mentioned a terrace at 1,521 feet on the Blue mountains near Collingwood, where a terrace large enough to contain several fields lies immediately below a sharp limestone cliff, and terraces at 1,420 feet, with rock cliffs in the rear, south of Meaford, on the same escarpment, showing plainly on both sides of a deep valley which cuts for a mile or two into the tableland. In the latter case, especially, it is hard to see how anything else than static water could have done the work. The same is true of the broad Proton plains which lie almost on top of the old island referred to, at an elevation of 1,630 feet, according to Doctor Spencer,* and consist of clays apparently waterlaid.

If the evidence just given be accepted, the waters by which the terraces were made may have belonged to a higher lake Whittlesey before the latter drained past Chicago.

\section{Beaches falither Nor'th}

Within the last two years beaches have been found at similar elevations to the north of the Great lakes also. One is found about 30 miles northwest of Michipicoten harbor, lake Superior, on the mountain portage between the waters of White river and Dog river. It is a very distinct terrace, of coarse but well rounded gravel and stones, 1,445 feet above the sea, and has been shown by Professor Willmott to occur again 4 miles to the north, on Pokay lake, at about the same level. On Obatonga lake, at the south end of the portage, there is a well marked and extensive sand terrace at 1,380 feet, and one or two lower ones occur near by, on the same chain of lake expansions, forming the upper part of Dog river, all of them being well above the nearest pass to Hudson bay, which is at Missanaibi, 70 miles to the east, and is 1,115 feet above the sea. It is possible that these terraces were formed in the body of water which made the highest beach on Keweenaw point, 150 miles to the southwest, now about 1,200 feet above the sea, the difference being accounted for by the greater amount of elevation toward the northeast.

If these terraces were of marine origin the arm of the sea which produced them must have been many miles broad and hundreds of feet

\footnotetext{
* The railway level for Proton is 1,582, and the track hav about the level of the plain, which seems to make the elevation 50 feet less than that mentioned.
} 


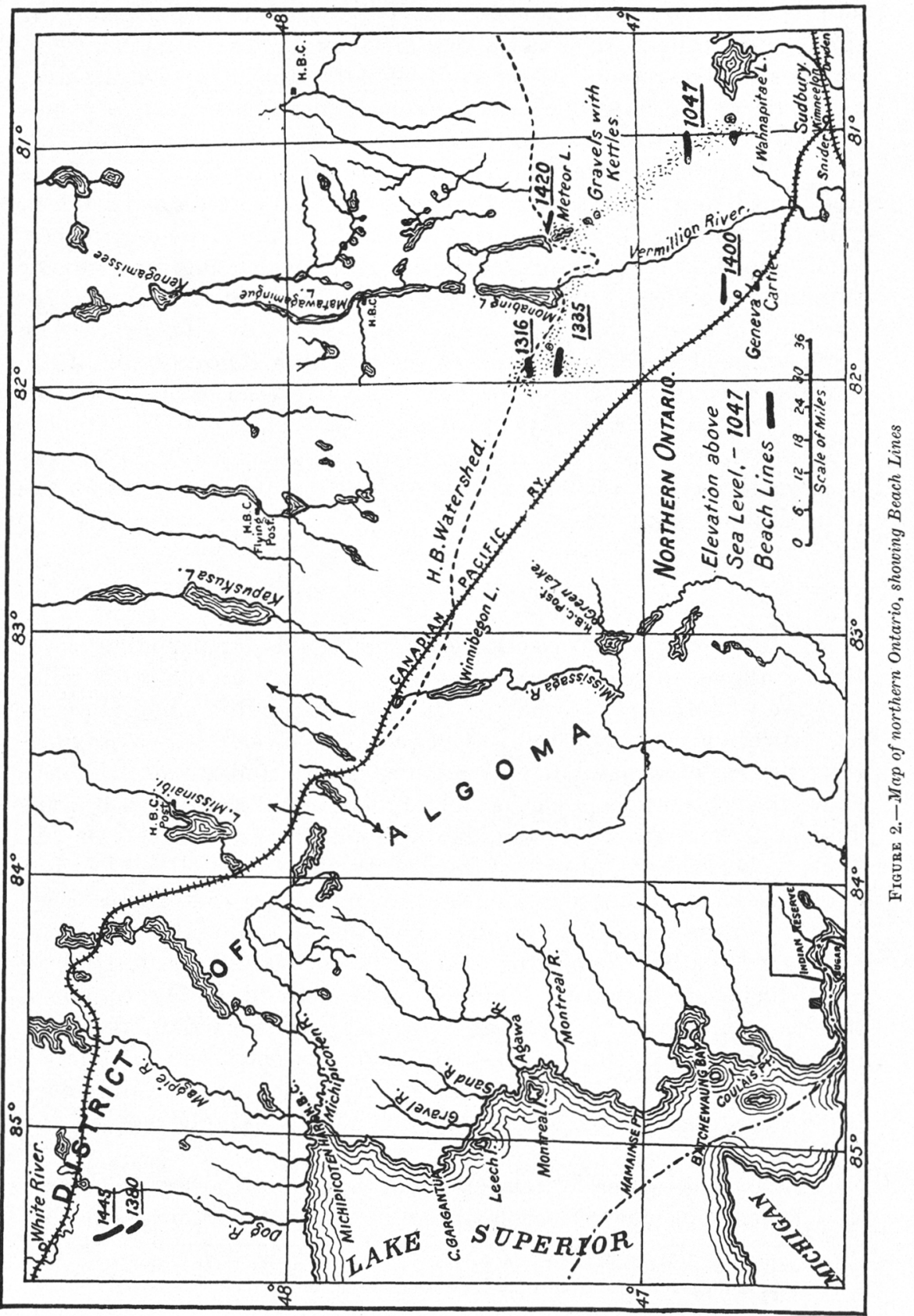


deep, and must have had connections both north toward an immensely enlarged Hudson bay and east toward the Atlantic. The rugged and mountainous Michipicoten region, which includes the highest known point of Ontario, 2,120 feet above the present sealevel, must have formed a large island.

The other high-level beaches are 200 miles to the southeast of the ones just described, on the watershed between the Saint Lawrence and $\mathrm{Hud}$ son bay waters, near Meteor lake, 40 miles northeast of Straight Lake station, on the Canadian Pacitic railway, and reachable only by canoes. The region consists mainly of wide sand and gravel plains having an elevation of 1,400 to 1,420 feet, with kames and also esker ridges rising 50 to 100 feet higher. The plains are often interrupted by kettles occupied by lakes, one of the largest being Meteor lake itself, which is 4 miles long. All these lakes have steep gravel banks, evidently not formed by their own feeble waves, but due no doubt to the burying of masses of ice in sand and gravel near the edge of a retreating ice-sheet. The melting of the buried ice gave rise to the cavities now filled by the lakes, some of the smaller ones with no visible outlet.

Meteor lake, as determined by aneroid, stands 1,393 feet above the sea and is reported to be 150 feet deep. It has the not unusual feature of draining both ways-to the southeast by a small stream into Wahnapitae river, which eventually reaches Georgian bay, and to the north by seepage through an esker ridge into Seven Mile lake, which belongs to the Matagami chain of waters emptying irto Hudson bay. This is proved by the fact that a narrow bay of the latter lake, approaching within 400 feet of Meteor lake, but at a level 35 feet lower, has clear water, like the lakes in the gravel plain, while the rest of Seven Mile lake has the usual brown water of muskeg regions.

That the sand and gravel of these lakes on the watershed are often well stratified and without the tumultuous arrangement found in kames has been proved by numerous test-pits sunk for prospecting purposes. Polished or striated stones have not been found in them, although the gravel and stones were carefully examined to determine their origin, a matter of interest, since the beds are more or less gold-bearing and have been taken up as placer claims. In some cases also there are terraces which must have been formed by water, as at the Onaping Gold Mining Company's sluices, where one has been cut in the side of an esker and covered with stratified yellow sand quite different from the bouldery gravel on which it is deposited.

The plains were probably formed of materials brought by subglacial streams and dropped at the margin of the ice, but whether in local lakes 
or a single large one can not be decided with the information now at hand. It should be mentioned that a sand terrace on the shore of Geneva lake, 45 miles south, has an elevation of about 1,400 feet, and that gravel plains, with kettle holes, at a height of 1,335 feet occur 20 miles to the west, on the divide between the waters of Spanish river, flowing into Georgian bay, and Matagami river.

The extensive gravel and sand deposits just referred to as occupying the watershed between Hudson bay and the Saint Lawrence system of waters were evidently formed at the ice margin during a long halt of the retreating glacier, and the low passes to the north and northeast were no doubt filled by the ice, preventing any connection with Hudson bay, whether the region stood at that time at sealevel or not. If the y were formed by salt water it must have been an extension of the gulf of Saint Iawrence; but it is probable that the much lower ground eastward toward lakes Temagami and Temiscaming, the latter only 581 feet above the sea, was still covered with a great lobe of ice, since in the lower parts the ice-mass must have been correspondingly thick, and hence slower in melting. This ice-lobe may even have extended down the lowlands near the Ottawa to the Saint Iawrence, and so have provided the supposed ice-dam of lakes Algonquin and Iroquois, in which case the Algonquin beach must be imagined as extended as far as Meteor lake, with a rather rapid differential elevation of 200 feet between Cartier and Meteor lake, 40 miles to the north.

The source of the immense beds of sand and gravel must have been glacial, since the rocky bills rising through the plains could not have afforded any large part of the materials, being entirely Laurentian, while much of the gravel is of Huronian rock. It appears as if the gravel must have been transported largely against the slope of the country, which falls away toward Hudson bay on the north and toward Temiscaming on the east. The glacial striæ seen in the region run from south to 25 degrees west of south. It is perhaps possible that subglacial streams may transport materials, even coarse gravel, up grade by means of the hydraulic pressure of the column of water derived from the high level of the icesurface in the rear, much as hydraulic elevators lift gravel in the western placer mines.

Southeast of Meteor lake a succession of similar sand and gravel plains stretches, with a few interruptions, for 40 miles, following in a general way the lake system of Vermilion river, though the headwaters of Montreal and Wahnapitae rivers also start from the neighborhood of Meteor lake. As one advances southeast the level gradually sinks by a series of steps until near lake Wahnapitae similar plains with lake-filled ket- 
tles are only 1,000 feet above the sea, though some terraces rise to 1,135 . The prospectors of the region, who have taken up almost the whole length as placer claims, think the gravels belong to an old river much larger than the Vermilion; but there is little except the general downward slope of the gravel plains to support this view. The gravels do not follow a single valley, but sometimes occupy two parallel valleys, with a total width of two or three miles, and sometimes cease altogether for a short distance. All the way down there are occasional terraces such as might be formed by wave action.

The fact that this stretch of 40 miles is every where auriferous, while sind and gravel areas of a similar kind to the south and west contain little or no gold, suggests a common source of the materials between Meteor lake and lake Wahnapitae; but the gold is generally exceedingly fine, the largest color seen by myself having a value of only four cents, and the scales are much rounded and flattened. suggesting that it may have been transported from a considerable distance, very likely by glacial means.

\section{Conclustons}

From the examples cited in the foregoing paper it will be seen that beach lines and terraces more or less well defined occur in Ontario at all levels from one or two hundred to fifteen or sixteen hundred feet above the sea, those of medium height being, as perhaps might be expected, more distinct and continuous than the lower and higher ones, since the opportunities for impressing themselves on the topography were greater. Through various circumstances, due probably to the rate of retreat of the ice and of the differential elevation of the region, some of the water-levels lasted much longer than others, good examples of the more permanent ones being afforded by the Iroquois, Nipissing, Algonquin, and Warren beaches. As a general rule, the higher beach lines are older than the lower ones, though there may be exceptions to this, as in the case of the Nipissing beach as compared with the Iroquois, the latter, though the lower, being the older of the two. This general succession in age from higher to lower may be accounted for largely by the theory of ice-dams, since the last ice-sheet retreated on the whole in a northeasterly direction, the various bodies of water following up its front and leaving the successive beach lines each more greatly tilted than the next one below, if we project their planes to the same vertical line at the northeast of the region. The Nipissing beach, however, not having been formed in an ice-dammed body of water, will to that extent be an exception. 
The processes of ice retreat and differential elevation must not be thonght of as uniform in rate or even as continuous at a varying rate. Probably the ice-front oscillated, as we know is the case with modern glaciers, and one lobe may even have advanced while others retreated, as some Alpine glaciers are shown to have done in the last century.

As regards differential eleration less is known, but the numerous marine terraces of the lower Saint Lawrence may imply an intermittent elevation, each terrace indicating a halt or a slowing up of the motion. On the other hand, many of the terraces on the north shore of lake Superior and on Michipicoten island show beach ridge after beach ridge with no sharp line between, often running almost continuously upward as one goes inland and covering a range of from 50 to 100 feet. In fact, if one tabulates the various beaches one finds that at one point or another there are shorelines at every level from the present lake to 475 feet above it, with no gap greater than 10 feet between the successive steps.* Above this, however, the intervals become greater and more irregular.

We know little of these earth movements, but it is possible that they begin haltingly, grow more rapid and uniform, and then slow down irregularly as the brakes are applied. Following the common opinion that the solid crust or lithosphere resting on the layer of plasticity or tektosphere, to use Murray's terms, does not yield instantly to the change of conditions, there may be comparatively sudden accommodations when the strain goes beyond endurance, and then periods of relative quiescence.

If the theory held by Mr Warren Upham and others is correct that the oscillations of level are produced by the loading down of the region with ice, producing subsidence, and then the removal of the load by the melting of the ice, allowing it to rise again, there should be a rough correspondence between the thickness of the ice-sheet and the level of the land, though we should expect the stage of elevation to be always in arrears, perhaps even to the extent of thousands of years. Doctor Gilbert's researches appear to show that the region is still being tilted up toward the northeast, though the Great lakes are supposed to have been free from ice ever since Niagara falls began its work.

The mechanism by which these changes of level are produced is, of course, obscure, but it may be supposed that as the region becomes weighted down the plastic layer some miles below the surface yields to the pressure and moves sluggishly outward in all directions, and after relief from pressure creeps back to the area that has been lightened. 
The subject is, however, too extensive and too vague to be discussed properly here, and has been introduced only to indicate the complexities of the problem presented by the great series of raised beaches.

The theory of ice-dams as causing the old water-levels seems preferable to the older one still held by some geologists, that the beaches were all formed at sealevel, and has been adopted in this paper, since it is scarcely conceivable that marine fossils should swarm as they do in deposits up to the level of 350 or 440 feet and suddenly cease above that level.

Those who consider the beaches marine may reply, of course, that the seashells which once existed in the higher beaches have all been leached out by percolating waters, or that shells were never deposited in them, owing to the difference in conditions, such as the coldness or brackishness of the waters in contact with the edge of the ice.

While it is true that the higher beaches are, in general, older than the lower deposits which have abundant shells, and so may have suffered more from weathering, it must not be forgotten that the comparatively ancient Algonquin sands near Georgian bay are often crowded with freshwater shells still in perfect preservation, though somewhat fragile. On the other hand, the supposition that the seawater was lifeless when the upper beaches were made seems hard to defend. The coldness of the water does not affect the matter, for arctic seas swarm with life almost as much as temperate or tropical ones; nor can one assume that the water of a sea that must have been connected by broad and deep channels with both Hudson bay and the Atlantic could be made so brackish as not to support marine life, when the later comparatively narrow and shallow inlet west of Montreal left beds filled with shells, in spite of the pouring in of fresh water from the upper lakes.

The objection sometimes made to the theory of ice-dams that no glacial mass could withstand the pressure of a head of water hundreds of feet in depth, and that the lakes would soon find an outlet beneath the ice, does not seem well taken, for no one knows how effective a dam a sheet of ice 100 miles broad and a thousand or several thousand feet thick would make. The modern glaciers whose ice-dammed lakes have been studied are too insignificant relatively to make a comparison of much value. As to the head of water to be held up, one may just as fairly assume a low one as a high one, for it is admitted that the whole region stood lower at the time the beaches were formed than now, and the depression may have been great enough to relieve the dam of much of the pressure. It is quite unnecessary, therefore, to assume an ice-dam holding up a huge lake 1,400 feet above sealevel, so as to form a beach now at that 
level, for the region may have risen most of the 1,400 feet since that time. In fact, the highest beaches may have been made at a time of great depression, and hence very little above the sea, while the lower and later ones may have had nearly the same position, owing to the advance in elevation as the ice-sheet thinned and retreated.

The later and lower deposits, which are clearly marine, were formed after the ice had been completely removed from the province of Ontario, and the climate of Ottawa had become practically the same as at present. These deposits are therefore in no sense interglacial. 